\title{
Judicial Populism and the Weberian Judge-The Strength of Judicial Resistance Against Governmental Influence in Hungary
}

\author{
Mátyás Bencze ${ }^{1}$ \\ ${ }^{1}$ Institute for Legal Studies, University of Debrecen, Debrecen, Hungary \\ Corresponding author: bencze.matyas@law.unideb.hu
}

(Received 20 September 2021; accepted 23 September 2021)

\begin{abstract}
The Hungarian judiciary has reacted to the political change of recent years in a twofold way. Some judges have resisted political pressure and decided cases according to the law and their conscience, while others, showing the signs of judicial populism, have deferred to the interests of the government. The paper explains the relationship between this twofold behavior and the bureaucratic tradition of the Hungarian justice system. The conclusion is that the bureaucratic model of organization has certain features that can make judges more resistant to political pressure, while other elements of the model can lead to judicial deference. Nonetheless, these latter elements are not necessary components of the 'Weberian' justice system.
\end{abstract}

Keywords: Bureaucratic justice system; self-understanding of judges; judicial populism; judicial formalism; Rule of Law in Hungary

\section{A. Introduction}

The aim of this Article is to show why the internal organizational model of courts and judicial ideology constitute important components of the ability of judges to resist political pressure. Political pressure on judges is present in any kind of political system. Nonetheless, in constitutional democracies the judicial branch is an autonomous and strong player in the public sphere which allows it to resist political pressure. ${ }^{1}$ However, in tyrannical political regimes or totalitarian dictatorships—such as the Soviet Union during the Stalin era-the judiciary completely loses its autonomy ${ }^{2}$ and becomes the mere executor of the central political will.

Mátyás Bencze, Professor of Law, School of Law, University of Debrecen. Senior research Fellow, Institute for Legal Studies, Centre for Social Sciences. This publication is part of the DEMOS project and has received funding from the European Union's Horizon 2020 research and innovation program under grant agreement No. 822590. Any dissemination of results here presented reflects only the authors' view. The Agency is not responsible for any use that may be made of the information it contains.

${ }^{1}$ The most recent example is the resistance of US courts at the end of 2020 against the pressure coming from the Trump administration in order to overturn the results of the presidential election. See Rosalind S. Helderman \& Elise Viebeck, 'The Last Wall': How Dozens of Judges Across the Political Spectrum Rejected Trump's Efforts to Overturn the Election, THE WAshington Post (Dec. 12, 2020), https://www.washingtonpost.com/politics/judges-trump-election-lawsuits/2020/12/12/ e3a57224-3a72-11eb-98c4-25dc9f4987e8_story.html (last visited Sept. 8, 2021).

${ }^{2}$ In this Article I prefer the word autonomy to independence because the former term is more connected to courts as actors in the political sphere, and here I am examining courts from a political perspective. The latter term rather refers to the constitutional guarantees of the separation of powers and thus fits an analysis written from the perspective of constitutional law scholarship.

(C) The Author(s) 2021. Published by Cambridge University Press on behalf of the German Law Journal. This is an Open Access article, distributed under the terms of the Creative Commons Attribution licence (https://creativecommons.org/licenses/by/4.0/), which permits unrestricted re-use, distribution, and reproduction in any medium, provided the original work is properly cited. 
Nonetheless, there are some intermediate forms of political systems between full-fledged constitutional democracies and totalitarian regimes. In these intermediate political regimes, ${ }^{3}$ courts can function in different ways. They can be the catalysts of the process of democratization and the guardians of constitutionalism when the rule of law is under attack. Or, courts can play a negative role if they help an authoritarian political leadership to survive or do nothing to defend a constitutional democracy when it is in danger.

One of the characteristics of intermediate regimes which are not yet totalitarian dictatorships is that they maintain an independent judicial system, or at least they refrain from the open oppression of the judiciary. ${ }^{4}$ That is why it is a real challenge for authoritarian and hybrid systems to influence judicial decisions - in politically sensitive cases - and to preserve the appearance of judicial independence at the same time. Following from this, sociological factors which make the judiciary more vulnerable or more resistant to this influence can be valid subjects of examination. When it comes to the strength of independence of individual judges many researchers usually focus on certain legal-formal elements of the institutional design of judicial systems, such as the rules of appointment and removal, the remuneration of judges, and their immunity to criminal procedure. ${ }^{5}$ Others hold that judicial independence depends on the strength of democracy-that is-judicial independence flourishes where none of the rival political parties can occupy the executive and legislative power for a long period. ${ }^{6}$

Nonetheless, there are other, less visible factors which also have the potential to influence individual judicial independence. There are authors, such as Lisa Hilbink, who suggest that it is not only the preferences of individual judges, but institutional factors such as judicial career systems and the self-understanding of judges which play a role in shaping the reaction of the judiciary to an authoritarian challenge.?

The main argument of this Article is that it is not the bureaucratization of the court system in itself which is a threat to judicial independence. This is only the case if it is coupled with a certain institutional arrangement of the promotional, evaluation, and disciplinary regime.

This Article proceeds as follows. Part B provides a brief overview of the different reactions of the Hungarian judiciary to the political pressure they have had to face since 2010. Part C, using the theoretical framework borrowed from Lisa Hilbink, shows that the institutional design of the Hungarian courts, formed in the pre-war and socialist era, has remained mostly unchanged up to the present day. Part D outlines the relationship between the institutional framework and the bureaucratic judicial mentality. Part E explores the divisions of self-understanding within

\footnotetext{
${ }^{3}$ According to the categorization of Freedom House, there are different kinds of intermediate regimes: semi-consolidated democracies, transitional or hybrid regimes, semi-consolidated authoritarian regimes, and consolidated authoritarian regimes. See Countries and Territories, FREEDOM H., https://freedomhouse.org/countries/nations-transit/scores (last visited Sept. 3, 2021).

${ }^{4}$ This is because, on the one hand, the vast majority of cases brought before courts are politically neutral and courts can decide these cases in an impartial and effective way. That is why independent courts can contribute to the domestic legitimization of the state itself. On the other hand, an independent judicial system can increase the trust in the legal system of a country in the eyes of other states and foreign business entities-international legitimacy. See Tamir Moustafa, Law and Resistance in Authoritarian States: The Judicialization of Politics in Egypt, in Rule By LAW: The POLITICS OF COURTS IN Authoritarian Regimes 133-39 (Tom Ginsburg \& Tamir Moustafa eds., 2008); and Zoltán Fleck, Jogszolgáltató MECHANIZMUSOK AZ ÁlLAMSZOCIALIZMUSBAN 105 (2001). Besides this, there are practical reasons for not taking effective political control of the judiciary. The implementation of such control can be costly because it would demand the extraction of resources from other, more important areas of political life.

${ }^{5}$ See Stephen B. Burbank, Barry Friedman \& Deborah Goldberg, Introduction, in JudicIAL INDEPENDENCE AT THE Crossroads: An Interdisciplinary Approach, (Stephen B. Burbank \& Barry Friedman eds., 2002); Amy Gordon \& David Bruce, Transformation and the Independence of the Judiciary in South Africa, in AFTER THE TRANSITION: JUSTICE, THE JUdiCIARY AND RESPECT FOR THE LAW IN SOUTH AFRICA (2007), http://www.csvr.org.za/docs/transition/3.pdf; Robert Stevens, Judicial Salaries: Financial Independence in the Age of Equality, 2 J. LEGAL HIST. 155 (1992).

${ }^{6}$ See McNollgast, Conditions for Judicial Independence, 15 J. ConTEMP. Legal Issues 105 (2006).

${ }^{7}$ See Lisa Hilbink, Agents of Anti-Politics: Courts in Pinochet's Chile in Rule By Law: The Politics OF Courts IN Authoritarian Regimes 1, 102-31 (Tom Ginsburg \& Tamir Moustafa eds., 2008).
} 
the Hungarian judiciary, seeking to explain the difference in judicial reactions to governmental pressure. Part F concludes.

\section{B. What is at Stake in Hungary?}

Hungary does not have a long history of democracy, and the recent developments show the decline of democracy and rule of law. ${ }^{8}$ That is why it can serve as a case study for the reaction of the judiciary to the abuse of political power by a hybrid regime. As for the political intervention in judicial activity, one can say that in Hungary there is no direct pressure on judges in relation to their decision-making activity; however, there are attempts by politicians to influence court decisions indirectly in various ways. ${ }^{9}$

Since Fidesz won the 2010 parliamentary election, the performance of the Hungarian judiciary has been heavily criticized by senior officials of the government, or politicians of the ruling party on many occasions. This was the case in 2016 when a judge acquitted all fifteen defendants in relation to a 2010 environmental disaster caused by toxic "red sludge," which killed ten people. ${ }^{10}$ When the ruling of the first instance court was issued, a leader of Fidesz publicly denounced the judgment as outrageous and initiated a parliamentary debate about the administration of justice. ${ }^{11}$ He stressed that the ruling party respected the "liberal" standard of judicial independence but democratic values such as transparency and accountability must be enforced, as well. ${ }^{12}$

In another case, the Curia, Supreme Court of Hungary, upheld the decision of the National Election Committee certifying the results of voting by mail in the 2018 parliamentary elections. ${ }^{13}$ The decision triggered a huge political controversy as Fidesz lost one seat due to some invalidated ballots. The prime minister, Viktor Orbán reacted to the decision of the Curia in an unprecedented manner, stating that "the Curia has taken away one mandate from our voters with this decision. The Curia has clearly and seriously interfered in the election ... it is obvious that the Curia was not up to this task intellectually." 14

\footnotetext{
${ }^{8}$ See the findings of the so-called Sargentini-report, European Parliament, Report on a proposal calling on the Council to determine, pursuant to Article 7(1) of the Treaty on European Union, the existence of a clear risk of a serious breach by Hungary of the values on which the Union is founded, (July 4, 2018) http://www.europarl.europa.eu/doceo/document/A-8-2018-0250_EN.html. Hungary has gradually slipped back year by year in Rule of Law and democracy world rankings. According to the World Justice Project, Hungary is in the penultimate place within the EU regarding to the status of Rule of Law. See WORLD JUSTICE PROJECT, RULE OF LAW INDEX 2017-2018, (Jan. 31, 2018) https://worldjusticeproject.org/our-work/research-and-data/wjp-rule-law-index2017\%E2\%80\%932018. In the ranking of The Economist, the Hungarian "flawed" democracy is the fourth worst out of $28 \mathrm{EU}$ countries in 2019. See The Economist, Economic and Geopolitical Insight Guiding the World's Organizations, http://www.eiu. com/Handlers/WhitepaperHandler.ashx?fi=Democracy-Index-2019.pdf\&mode=wp\&campaignid=democracyindex2019. In the report published by Freedom House, Hungary is qualified as a "transitional or hybrid regime". See Countries and Territories, FREEDOM House, https://freedomhouse.org/countries/nations-transit/scores (last visited Sep. 3, 2021).

${ }^{9}$ See generally AMNESTY INTERNATIONAL, Status of the Hungarian Judiciary (2021),https://www.amnesty.hu/wp-content/ uploads/2021/02/Status-of-the-Hungarian-judiciary_EN_FINAL-1.pdf; AMNESTY INTERNATIONAL, Fearing the Unknown (2020), https://www.amnesty.hu/fraudulent-fear-rules-among-hungarian-judges/; Hungarian Helsinki COMmITTEE, Attacking the Last Line of Defence (2018), https://www.helsinki.hu/wp-content/uploads/Attacking-the-Last-Line-of-Defense-June2018.pdf.

${ }^{10}$ See https://en.wikipedia.org/wiki/Ajka_alumina_plant_accident (last visited Sept. 8, 2021)

${ }^{11}$ Veszprémi Törvényszék [Regional Court of Veszprém] 12.B.39/2012 (Hung).

${ }^{12}$ See Bírósági itéletekről vitázna a Fidesz, MAGYAR NeMZET (Jan. 31, 2016), https://mno.hu/belfold/birosagi-iteletekrolvitazna-a-fidesz-1326421. In his statement he also criticized another judgment of the court because he considered it too lenient in the criminal case of the former deputy mayor of Budapest, a member of the opposition Socialist party.

${ }^{13}$ Kúria [Curia of Hungary] Kvk.III.37 503/2018/6 (Hung.). This paragraph is based on a manuscript written by the author and Ágnes Kovács, entitled "Judicial independence and models of court administration".

${ }^{14}$ See Sztefan Dzindzisz, Orbán a választásokról: a Kúria “intellektuálisan nem nőtt fel a feladatához”, NAPI.HU (May 5, 2018), https://www.napi.hu/magyar_gazdasag/orban_a_valasztasokrol_a_kuria_intellektualisan_nem_nott_fel_a_feladatahoz.661884.html.
} 
In 2019, a man who had been sentenced to five years in prison murdered two of his children just after he was released on parole. ${ }^{15}$ According to the Head of Prime Minister's Office, the previous punishment was "unacceptably lenient" and he added that "had he not been sentenced so leniently he would still be behind bars and the children would be alive". ${ }^{16}$ The Minister of Justice called for the President of the Curia to launch an enquiry to examine whether the sentencing practice of Hungarian criminal courts is severe enough. ${ }^{17}$ Most recently, the prime minister openly refused to pay any compensation ruled by Hungarian courts for prisoners who had suffered from humiliating prison conditions, because, he said, in these cases "the law was applied in an incorrect manner." 18 According to the state secretary of the Ministry of Justice, the justification for this decision, amongst others, is that the so-called "prison business" "erodes public trust in the administration of justice."19

These worrying episodes show how the government attempts to put permanent pressure on judges. ${ }^{20}$ As for the reactions to the above-mentioned-and some other-unfounded political attacks on judges and judicial decisions, it was a common feature that the competent administrative leaders stood up for judicial independence, but not in a determined manner. They adopted a rather defensive position and sometimes blamed the judges themselves for their practice, or for a certain decision. $^{21}$

The reactions of the judiciary have followed two directions. There are cases in which the judiciary deferred to the political will and decided accordingly. For example, in October 2018, the Curia acquitted a journalist from charges of violent attack against refugees on the HungarianSerbian border in $2015 .^{22}$ The Curia, by reversing the judgments of lower courts, found that the journalist did not commit the crime of public nuisance when, without any lawful reason, she tripped and kicked refugees fleeing the police on the border. According to the Curia, the journalist's act was not blatantly antisocial with regard to the public peace which had been already disturbed by the migrants themselves. ${ }^{23}$ In this case, the judges handed down a judgment that can be difficult to justify on professional grounds. ${ }^{24}$ However, the judgment obviously fits into the hostile approach of the government-backed by broad public support-towards migrants. In another case in 2021, a panel of the Curia ordered a publishing company of a Hungarian weekly to pay compensation, because one of its journalists mocked ancient Hungarian warriors in an

\footnotetext{
${ }^{15}$ See Family Drama Claims Three Lives, Hungary Today (Dec. 16, 2019), https:/hungarytoday.hu/family-dramamurder-gyor-three-lives/.

${ }^{16}$ See Gov't Mulling Law to Prevent Release of Murderers on Probation, Hungary Today (Dec. 19, 2019), https:// hungarytoday.hu/gyor-murder-law-murderers-probation/.

${ }^{17}$ See Justice Minister to Tighten Rules on Conditional Release of Murder Convicts, HungaRY Today (Jan. 7, 2020), https:// hungarytoday.hu/gyor-murder-justice-minister-rules/.

${ }^{18}$ See Péter Magyari, Elöre szólt az ellenzék, hogy botrány lesz a rabok kompenzációjából, 444.HU (Jan. 23, 2020), https://444. hu/2020/01/23/elore-szolt-az-ellenzek-hogy-botrany-lesz-a-rabok-kompenzaciojabol.

${ }^{19}$ See Government Suspends Payment of Prison Awards with Immediate Effect, WEBSITE OF THE HUNGARIAN GOVERNMENT (Jan. 18, 2020),

https:/www.kormany.hu/en/ministry-of-justice/news/government-suspends-payment-of-prison-awards-with-immediate-effect.

${ }^{20} \mathrm{Criticism}$ of judicial decisions from politicians is ubiquitous in fully-fledged democracies. A distinctive feature of the Hungarian situation is that the Fidesz-led government dominates the Hungarian media, thus statements by government politicians have an extremely large impact on the public sphere. See Ágnes Urbán, Gabor Polyák, and Z. Szász., Hungary: Media Transformation Derailed, in MEDIA IN THIRD-WAVE DEMOCRACIES: SOUTHERN AND CENTRAL/EASTERN EUROPE IN A COMPARATIVE PERSPECTIVE 136-63 (Péter Bajomi-Lázár ed., 2017).

${ }^{21}$ See Zéró tolerancia jöhet a bírósági ügyek halogatása ellen, NÉPSZAVA (June 23, 2015), https://nepszava.hu/1061270_zerotolerancia-johet-a-birosagi-ugyek-halogatasa-ellen; ECHO TV, A Kúria érvénytelenített négyezer levélszavazatot - Darák Péter, YouTube (May 7, 2018), https://www.youtube.com/watch?v=npMIRZLAOuI.

${ }^{22}$ This paragraph is also based on the manuscript titled "Judicial independence and models of court administration".

${ }^{23}$ Currently, only the press release is available at KURIA, A megvádolt operatör cselekménye nem valósította meg a garázdaság vétségét (Oct. 30, 2018), https://kuria-birosag.hu/hu/sajto/megvadolt-operator-cselekmenye-nem-valositotta-meg-garazdasagvetseget.

${ }^{24}$ According to the decision, any physical attack which does not cause bodily harm to other person should remain unpunished if it is committed at a place where there is "public turmoil".
} 
article. ${ }^{25}$ In the justification of the verdict the court said that the use of the expressions "Hungarian-smelling immigrants" and "Hungarian bandits" "insult[ed] the honor of the Hungarian nation.". That decision can hardly be explained independently from the nationalist rhetoric of the government.

Other judges, who have gone against the clear interest of the government or rendered unpopular judgments, provide evidence that the judiciary makes efforts to maintain its autonomy. Recently, this autonomy has been reflected in the attitudes of judges acquitting homeless people of offences or lodging a motion with the Constitutional Court based on the view that the new law which made "sleeping out of doors" illegal is unconstitutional. ${ }^{26}$ Or, in other cases, judges in criminal cases have acquitted politicians from opposition parties who were, otherwise, the target of the Fidesz-led government. ${ }^{27}$

While it is not a surprise that members of the judiciary sooner or later defer to permanent pressure, it is quite interesting that after almost ten years of permanent pressure one can find judges who can resist governmental influence. That is why a careful socio-legal and historical scrutiny is needed in order to explore the factors which influence the behavior of judges in the Fidesz era. I will focus on the institutional structures that have a significant impact on the self-understanding of the Hungarian judiciary.

\section{Theoretical Framework}

Lisa Hilbink has pointed out that the strength of judicial resistance against an authoritarian regime can depend on certain organizational and structural conditions which, at first glance, seem to be far removed from having any influence on judicial behavior. Hilbink argues that the internal career system of judges — especially the assessment and promotion of judges — can strengthen the dominant judicial ideology. ${ }^{28}$ If this ideology is in line with the ideology of the political regime, then courts will defer to the political will even if the judicial system enjoys wide institutional autonomy.

As Hilbink explains, the dominant judicial self-understanding in Chile had been the seemingly "apolitical judge" a long time before the onset of the authoritarian regime, for example, being faithful only to the "text of the law" and not being sensitive to "rights" and "principles" behind the text, which was advantageous to the right-wing conservative politicians. The apolitical attitude was in accordance with Pinochet's "law and order" doctrine. Through its whole existence from 1973 to 1990, the regime presented itself as the savior of the rule of law and emphasized the importance of the independence of the judicial branch. That is why judges did not have to give up their own self-understanding. ${ }^{29}$

The structure of the court system greatly contributed to the maintenance of this ideology. "The Supreme Court held tremendous power over the judicial hierarchy, through which it induced conservatism and conformity among appellate and district court judges." 30 This "tremendous power" was manifested in the promotion, assessment, and disciplinary procedures which were controlled by the Supreme Court. If a judge aspired to rise in judicial rank, she had to please her superior. As the dominant judicial ideology amongst Supreme Court judges was the "apolitical" one, such a system of promotion strengthened the apolitical and also conformist attitude amongst judges

\footnotetext{
${ }^{25}$ Kúria Pfv.IV.20.199/2020/7 (Hung.).

${ }^{26}$ See Alkotmánybíróság (AB) [Constitutional Court] III 01628/2018 (Hung.)

http://public.mkab.hu/dev/dontesek.nsf/0/2BA8668E09472DB8C1258337004BC40A?OpenDocument.

${ }^{27}$ See One of Many of Fidesz-inspired Show Trials: The Hagyó Case, Hungarian SPeCtrum, (Jul. 6, 2015) https://hungarianspectrum.org/2015/07/06/one-of-many-of-fidesz-inspired-show-trials-the-hagyo-case/; Kettős felmentés, VISZKISDOBOZ.BLOG.HU (Mar. 01, 2014), https://viszkisdoboz.blog.hu/2014/03/01/171_kettos_felmentes?utm_source= bloghu_megosztas\&utm_medium=facebook\&utm_campaign=blhshare.

${ }^{28}$ Hilbink, supra note 7 , at 120.

${ }^{29}$ Hilbink, supra note 7 , at $126-29$.

${ }^{30} I d$. at $129-30$.
} 
at all levels of the judicial hierarchy. These kinds of judges do not have the capacity to stand against an authoritarian government. ${ }^{31}$

The example of Chile shows that it is a meaningful enterprise to study the history of judicial ideology and the institutional arrangements of the judicial system in Hungary, if our aim is to explain the reaction of Hungarian judges to political pressure.

\section{The Internal Court Structure and Evaluation of Judges in Hungary}

In the construction of a modern court system, Hungary followed the so-called Prussian model. According to this model, the judge is a well-educated, competent, and responsible bureaucrat, a legal specialist whose primary duty is the unbiased and impersonal application of the law. ${ }^{32}$ A judge is politically neutral and gains legitimacy from a high-level of professional competence. This model can also be characterized as a Weberian one. ${ }^{33}$ It is far removed from the common law concept of a judge, in which the judge is a charismatic and wise adjudicator who dispenses justice and takes personal responsibility for their decisions. ${ }^{34}$ Nonetheless, it is important to note that the Weberian model of adjudication does not imply a "blind"or mechanical application of the written law. The law does not only consist of legal norms - but of rights, principles, and values - and professional judicial competency covers the correct application of all legal arguments.

With regards to Hungary, another feature of the bureaucratic judiciary has been that from the beginning the judge has been a part of a hierarchic organization ${ }^{35}$ in which their activities outside the adjudication itself have also been controlled by other, higher-ranking judges.

The implementation of the bureaucratic model of the judiciary was an important step at the time of the creation of the modern court system. The transformation of the Hungarian justice system was necessary in the second half of the nineteenth century because it had certain feudalistic features before $1869 .{ }^{36}$ There were different courts for different social groups-aristocrats, peasants, and so on-and the court system was not separated from the local public administrative system. There was no unified procedure, nor organizational law for the courts. Moreover, judges - who did not require a university law degree-were elected by the aristocrats of the counties - administrative country regions - thus why their decisions were often arbitrary. ${ }^{37}$

These were the main challenges the judicial system had to face at that time. The legislation responded to these challenges by creating a centralized, unified, and bureaucratic judicial system. One of the results of the reform was that professional competence and personal integrity were required from judges. ${ }^{38}$ The reform also created the conditions for individual judicial independence-irremovability, autonomous decision-making, the prohibition on moving a judge to another court without his consent-among many others. At the same time, it put less emphasis on organizational independence, because the judicial system operated under the administrative control of the Ministry of Justice. The minister of justice was on several occasions accused of

\footnotetext{
${ }^{31} I d$. at 131.

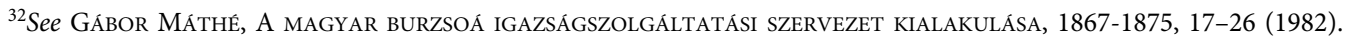

${ }^{33}$ See MAX Weber, ECONOMY AND Society 853 (Guenther Roth \& Claus Wittich eds., 1978).

${ }^{34}$ See Rene David \& John E. C. Brierly, Major Legal Systems in the World Today 373-74 (1985); JOHN BELL, JUDICIARIES WITHIN EUROPE 329-49 (2006)

${ }^{35}$ See generally Mirjan Damaška, Structures of Authority and Comparative Criminal Procedure, 3 YALE L.J. 481 (1975).

${ }^{36}$ Actually, it was the Austrian Habsburg emperor who started to modernize the Hungarian court system after the suppression of the revolution in 1849, but in 1861 the old system was mostly restored. See László Papp, Az elsőfokú bíróságok rendszere 1849-1871 között in ÜNNEPI TANULMÁNYOK MÁTHÉ GÁBOR OKTATÓI PÁlYÁFUTÁSÁNAK 50 JUbiLeumÁra, 307-314 (Norbert Kis \& Zsuzsanna Peres eds., 2017).

${ }^{37}$ László Papp, Bihar vármegyei törvényszékek a 17. századtól 1871-ig in A JOGSZOLGÁLTATÁs TÖRTÉNETE BeretTyóújfaluban 16-18 (Zoltán Megyeri-Pálffi ed., 2017).

${ }^{38} 1869$. (Act IV of 1869 on the Exercise of Judicial Power) (Hung.).
} 
taking the political views of the applicants into consideration when deciding on judicial appointments. ${ }^{39}$

As a part of the new system, laws on the mechanism of administrative control over the courts were adopted in 1871 and $1891 .^{40}$ The latter obliged higher court leaders to carry out a detailed assessment on an annual or bi-annual basis-depending on the level of the court evaluated-of the activity of lower courts. Higher courts were under the control of the minister of justice; however, their activity was not subject to regular assessment. This regular assessment focused on the compliance of judges and other court staff with internal administrative rules, on the way they handled complaints, and on the timeliness of adjudication. Although the law did not specify it, the assessment concentrated more on the work of individuals - especially on judges' work - than on the activity of the court as a whole. For example, if a major violation of administrative duties was revealed, higher court leaders could impose fines on lower-level judges. The observations made by the assessor judge were also recorded, and these influenced the career of the judge assessed. ${ }^{41}$

At the time of the transition from a feudalistic judicial system to a liberal one, the strict, bureaucratic control over judges was very reasonable. Nonetheless, it pushed the judicial self-understanding toward that of a subordinate official.

After World War I, the Austro-Hungarian Empire was dismembered and Hungary became a sovereign country. Due to the shock of the defeat-the territory of Hungary was reduced to onethird of its original size - and later, because of the Great Economic Depression, Hungary gradually drifted towards an authoritarian political regime, where the Rule of Law was not the central value of state. ${ }^{42}$ In spite of this, due to the organized lobbying activity of the judiciary, the Hungarian legislation adopted a new law in 1920 that strengthened the independence of the judges by introducing a more or less automatic promotional and remuneration system. ${ }^{43}$ Nonetheless, the control of the minister of justice over the judiciary remained strong, and this made the justice system similar to other administrative organs. In addition to this, the "authoritarian atmosphere" within the court system was strengthened, as was manifest in the decisive role of the higher-ranked judges in the promotion of lower court judges. ${ }^{44}$

During the socialist era, the bureaucratic character of judicial work became stronger. In the 1950s the government had the right to remove judges from their position or transfer them to another court without their consent. In many cases, Communist Party leaders ordered the courts to make decisions in favor of the will of the party. ${ }^{45}$ Nonetheless, even in this period, one can find criminal judgments in cases of workers who did not achieve the expected production-goals where judges, by deploying formalistic legal arguments, avoided applying the order of the Supreme Court which would have resulted in excessively severe punishment in petty cases. ${ }^{46}$

From the mid-60s, in the age of the "soft dictatorship" or "goulash communism", 47 direct political influence on courts gradually disappeared; however, the bureaucratic mentality of judges

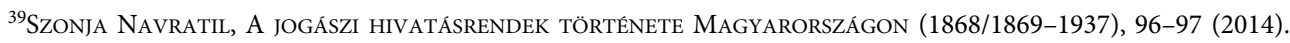

${ }^{40} 1871$. (Act XXXI of 1871) (Hung.); 429/1891. (Decree no. 429/1891 of the Minister of Justice) (Hung.).

${ }^{41}$ See Judit BALOGH, Fejezetek a Hajdúszoboszlói Királyi Járásbíróság szervezés- és itélkezéstörténetéböl in A JOGSZOlgáltatás tÖRTÉNETE HajdúsZOBOSZlón, 55-69 (Zoltán Megyeri-Pálffi ed., 2019).

${ }^{42}$ KÁLMÁN KulCSÁR, Jogalkotás és jogrendszer in MAGYARORSZÁG A XX. SZÁZADBAN 468 (István Kollega Tarsoly ed.,19962000); David Kosař, Jiří Baroš \& Pavel Dufek, The Twin Challenges to Separation of Powers in Central Europe: Technocratic Governance and Populism, 3 Euro. Const. L. Rev. 437 (2019).

${ }^{43}$ Act XX of 1920 on the Status of Crown Judges and Crown Prosecutors.

${ }^{44}$ Navratil, supra note 39 , at $121-38$.

${ }^{45}$ Attila Horváth, A magyar bírósági szervezet története a szovjet típusú diktatúra idején (1945-1990), 1-2 JOGTÖRTÉNETI SZEMLE, 128 (2017).

${ }^{46}$ TAMÁs GYEKICZKY, Ideológiai érvek a munkafegyelem megsértőivel szemben 1952.-ben hozott büntető bírósági itéletekben in Acta Facultatis Politico-Iuridicae Universitatis Scientiarum Budapestinensis de Rolando EÖtVös Nominatae 200-10 (Gábor Hamza ed., 1985).

${ }^{47}$ From 1963 until 1989 in Hungary, the authoritarian political leadership gradually abandoned the forms of open aggression and threat toward the citizens and tried to gain legitimacy by creating social and financial security for the people. Besides
} 
was further strengthened. Judges were generally conceived of as technocrats and apolitical civil servants. ${ }^{48}$ It was relatively easy to maintain this self-understanding, because judges did not need to adjudicate in politically sensitive cases. The government handled its critics outside the courtsfor example, they were dismissed from their jobs - and judicial review of decisions of state organs -administrative court cases - was practically non-existent. ${ }^{49}$ In criminal cases the crucial phase of the procedure was the police investigation and the criminal judge only checked the validity of the pieces of evidence presented by the police and the prosecutor. Thus, the role of the court in criminal cases had become mostly formal..$^{50}$

In the process of the post 1989 political transition, ideas of reforming the judicial system received surprisingly little attention from the designers of the new constitutional set up. They focused only on the formal constitutional guarantees of judicial independence, while changes to the internal court structure were not on the agenda. ${ }^{51}$ This can be explained by the fact that judges were generally conceived of as neutral bureaucrats in the late socialist period, and not as servants of the communist regime. Thus, while organizational independence was guaranteed, the individual independence of judges remained limited to their freedom of decision-making. ${ }^{52}$

That is why after the political transition, the control of judges' administrative activity by their superiors remained at the same level. This means that serious administrative decisions such as case-assignment, individual assessment of judges, promotion, initiation of disciplinary procedures, and-to a certain extent-salary increases, remain within the court leaders competence. ${ }^{53}$ There are only a few vague criteria in the relevant laws in relation to the exercise of these powers.

One telling example of the impact of administrative control over judges is the case of regular evaluation. Under the statute in effect, judges are, as a general rule, first assessed in the third and then in the sixth years from their appointment, and after that, in every eighth year. ${ }^{54}$ The first evaluation is of great importance because junior judges are appointed for a determined three year "probationary" period. ${ }^{55}$ If a judge proves to be incompetent at the first evaluation their judgeship ceases automatically. This regulation can be criticized on the ground that the temporary nature of the first appointment maximizes the pressure on the judge to align with the judicial practice of the closest court of appeal. As the judges of the courts of appeal, generally regional courts, evaluate the junior judge, they can achieve a permanent post if they meet the expectations of the upper court judges. This situation may discourage independent judicial thinking and thus may threaten the personal independence of the judge. ${ }^{56}$

Apart from the regular inspection, an extraordinary evaluation can be carried out in specific situations/circumstance-such as signs of professional incompetence, skipping

\footnotetext{
this, it introduced some civil liberties in limited forms. See Zvi Gitelman, The Politics of Socialist Restoration in Hungary and Czechoslovakia, 2 Compar. Pol., 187-210 (1981); Heino Nyyssönen, Salami Reconstructed: 'Goulash Communism’ and Political Culture in Hungary, 1-2 CAHIERs Du MONDE Russe, 153-72 (2006).

${ }^{48}$ FLECK, supra note 4 , at 104.

${ }^{49}$ For the mentioned example see János Weiss, A filozófusper és következményei, 3 Fordulat, 169-172 (2010).

${ }^{50}$ FLECK, supra note 4, at 137.

${ }^{51}$ Béla Révész, Változások a bírósági rendszerben 1945 és 1989 között, 1-2 JOGTÖRTÉNETI SzEMLE 122 (2017).

${ }^{52}$ László Ravasz, Bírói függetlenség és a tisztességes eljáráshoz való jog, 3-4 DeBRECENI JOGI MưHHELY (2015), http://www. debrecenijogimuhely.hu/archivum/3_4_2015/biroi_fuggetlenseg_es_a_tisztesseges_eljarashoz_valo_jog/.

${ }^{53} I d$. at 46.

${ }^{54}$ This part of the Article is based on the author's previous work. See Mátyás Bencze, Ágnes Kovács \& Zsolt Ződi, The Evaluation and Development of the Quality of Justice in Hungary, in HANDLE WITH CARE. AsseSSING AND DESIGNING Methods for Evaluation and Development of the Quality of Justice 145-47 (Francesco Contini ed., 2017). For specific provisions, see 2011. évi CLXII. (Sections 71 to 77 of the Act CLXII of 2011 on the Status of the Judiciary) (Hung.).

${ }^{55} 2011$. évi CLXII. (Section 23 of the Act CLXII of 2011 on the Status of the Judiciary) (Hung.).

${ }^{56}$ See Venice Commission, Opinion on Judicial Appointments, CDL-AD (2007) 028, http://www.venice.coe.int/webforms/ documents/default.aspx?pdffile=CDL-AD(2007)028-e.
} 
compulsory training, more than two years undue delay in a case tried, or if the judge themselves requests the evaluation for some reason. ${ }^{57}$

During both the regular and extraordinary types of assessment, the head of the affected department - or another experienced judge appointed by them-assesses the quality of the judge's work, including the observation of substantive and procedural laws and case managerial regulations. Trial conduct is also evaluated.

An order of the President of the National Office for the Judiciary (NOJ) contains a very detailed list of the assessment criteria-NOJ No. 8 of 2015-for both above mentioned types of assessment. The assessment has three aspects: The quantitative, number of trial days, number of finished cases etc., and the qualitative, legal competence, trial conduct, judicial writing, aspects of the judicial work, as well as the evaluation of judicial skills such as focused thinking, working capacity, and the ability to make decisions in a determined manner.

With regards to the quantitative evaluation, the activity of the judges is assessed in a statement based on caseload and activity-related data, as well as second instance and review decisions, which are taken into consideration during the overall assessment.

The qualitative part of the evaluation and the checking of judicial skills are conducted using the following methods. A certain number of judgments-which became final in the first instancedelivered by the judge are examined. Furthermore, "panel justice notes" prepared in the examined period are considered during the assessment. ${ }^{58}$ As part of the qualitative assessment, the persuasive force of the oral and written justifications provided by the assessed judge has to be evaluated as well. The opinion of the head of the department competent in the legal area is also taken into consideration. The assessor judge examines the files of cases in which parties submitted complaints over undue delays or for other reasons. Though the relevant law and regulation of judicial assessment does not list the proportion of the quashed/changed judgments of the assessed judge as a quality indicator, it plays a crucial role in the assessment as the assessor judge has to evaluate the "quality of the adjudicative activity" as well. ${ }^{59}$

The result of the evaluation does not affect the salary of the assessed judge. However, if they apply for a higher judicial position, the result is taken into consideration in the promotion process.

As one might notice, the judge's professional activity is assessed by their immediate professional superior who knows them personally, and is the person on whom their professional career is decisively dependent. This situation raises the problem that apart from the detailed assessment criteria, the assessor's personal opinion of the examined judge may play a role in the assessment. Therefore, judges in lower courts are generally encouraged to align their judicial activity predominantly to the viewpoint of the reviewing second instance panel, as well as to its judicial style, regardless of any opposing professional convictions. ${ }^{60}$ This situation affects autonomous judicial thinking even if a reasonable uniformity in the practice of lower courts is also desirable.

Nonetheless, the evaluation of judges focuses mainly on the professional quality of their activity, which strengthens the attitude of an unbiased legal specialist. In addition to this, the fact that the vast majority of Hungarian judges socialize within the court right after university and without any previous professional experience outside of the court facilitates the maintenance of the Weberian attitude through the generations of judges. ${ }^{61}$

\footnotetext{
${ }^{57}$ See Bencze et al., supra note 54 .

${ }^{58}$ Panel justice notes are memos made by the chief justices of the appellate panels when reviewing appeals. Regarding a quality-check, these panel notes are useful because they contain remarks on the writing and argumentative style of the judge which are typically not mentioned in appellate judgments.

${ }^{59}$ NOJ No. 8 of 2015 , sections 11 and 34 .

${ }^{60}$ The Hungarian situation in this regard is very similar to that of the German courts. RÜDIGER LAUTMANN, JUSTIZ - DIE stille Gewalt. Teilnehmende Beobachtung und entscheidungssoziologische Analyse, 116-19 (2011).

${ }^{61}$ Nonetheless, it is also true that the lack of professional experience other than that acquired in courts can have a detrimental effect on the quality of judicial practice. See Attila Badó \& Mátyás Bencze, Quality of justice in Hungary in European context, 2 Forum: ACTA Juridica ET POLITICA 5 (2016).
} 


\section{E. Judicial Ideologies and Strategies in Hungary \\ I. Legalism}

As for judicial self-understanding, the bureaucratic design of court organization gives more support to the formalist judicial approach than to any other kind. ${ }^{62}$ Judicial formalism, also labelled as textualism, is generally characterized as an adjudicative style where the judge takes the text of the statutes and their linguistic interpretation into consideration in their reasoning, while ignoring other relevant legal arguments such as the principles and values behind the existing law. ${ }^{63}$ The ideology behind formalism is legalism. Legalism reduces the complex question of the justifiability-correctness - of legal decisions to the question of the conformity of the decision to the existing law. ${ }^{64}$

The formalist model of adjudication in which the judge is a neutral law-applier-an official of the state- traditionally over-emphasizes the value of legal certainty, ${ }^{65}$ and creating legal certainty was the main motive behind the construction of the modern judicial system in Hungary. Many authors share the view that formalism has remained the predominant approach in Central and Eastern European countries even today, while the courts in Western-European countries have moved toward non-formalistic decision-making in which enforcement of values other than legal certainty-constitutional and EU law principles-also plays a role in judicial reasoning. ${ }^{66}$

The question here is whether a legalist judicial ideology which backs the formalist judicial style can explain the behavior of Hungarian judges in deciding politically sensitive cases. It is beyond any doubt that a formalist judicial approach can explain both deferential judgments and decisions against governmental policies. On the one hand, formalism leads to a pro-governmental judicial practice if the legislator drafts the laws in a clear and unambiguous manner. Under these circumstances formalist judges decide "easy cases" according to the ordinary meaning and doctrinaldogmatic - background of the text of the law.

On the other hand, however, clear and unambiguous legal rules can also result in decisions which are against the governmental interest. This is because the legislator can never predict the characteristics of future cases where the legislated law has to be applied. It is entirely possible that a law that was originally designed to serve a government policy in certain cases requires a decision against the government's interests. Or, the government's policy can change after the adoption of the law. ${ }^{67}$ Thus, a legalist attitude cannot be connected either with judicial deference or with judicial resistance.

What is more important is that in other cases, which were also easy ones, the court went beyond the textual and doctrinal meaning of the law and decided the case by taking other arguments into consideration. ${ }^{68}$ These judgments can be characterized as populist, opportunist, or as

\footnotetext{
${ }^{62}$ See Bojan Bugaric, The Rule of Law Derailed: Lessons from the Post-Communist World, 2 Hague J Rule LAW, 178-179 (2015); Antal Örkény \& Kim Lane Scheppele, Rules of Law: The Complexity of Legality in Hungary, 4 INT'L J. SocIO. 76 (1996/1997).

${ }^{63}$ Frederick Schauer, Formalism, 4 YALE. L. J. 509, 519 (1988).

${ }^{64}$ Mátyás Bódig, Adalékok a jogi érvényesség jogelméleti problémájának tisztázásához, 1 JOGELMÉLETI SZEMLE (2003), http:// jesz.ajk.elte.hu/bodig13.html.

${ }^{65}$ See WeBER, supra note 33, at 811.

${ }^{66}$ See Tamara Ćapeta, Courts, Legal Culture and Eu Enlargement, 1 CroAtian Y.B. Eur. L. \& Pol'Y, 23 (2005); Anders Fogelkou, East European Legal Thinking, 4 RGSL WorKING PAPERS, (2002), https://www.rgsl.edu.lv/uploads/workingpapers-list/26/rwp4fogelklou.pdf; Zdeněk Kühn, Worlds Apart. Western and Central European Judicial Culture at the Onset of the European Enlargement, 3 AM. J. Comp. L., 531 (2004); Denis Galligan \& Marcin MatczaK, Strategies of Judicial Review, Exercising Judicial Discretion in Administrative Cases Involving Business Entities $28-35$ (2005); Bernard SCHWARTZ, THE STRUggle FOR CONSTITUtional Justice IN Post-Communist Europe 236-37 (2000); Gerda Falkner \& Oliver Treib, Three Worlds of Compliance or Four? The EU-15 Compared to New Member States, 2 J. COMmOn MKTs. STUd. 293 (2008).

${ }^{67}$ This was exactly the case in cases of compensation for damages suffered by prisoners. See Wrapping Up: Fidesz Itself Wrote the "Absurd Law" on Prisoners' Compensation, Hungarian SPECTRum (Jan. 18, 2020), https://hungarianspectrum. org/2020/01/18/wrapping-up-fidesz-itself-wrote-the-absurd-law-on-prisoners-compensation/.

${ }^{68} \mathrm{Id}$. See the public nuisance case above, where an obviously criminal behavior remained unsanctioned. The formalist, textualist, approach would have required that the camerawoman be found guilty.
} 
value-oriented, but still as formalist, that is, courts did not adhere to the literal interpretation of the relevant laws. ${ }^{69}$

Finally, cases also include those that are not easy, "hard cases", that is to say, those in which the decision could not be deduced simply from the text of the relevant law or from a certain doctrinal concept. ${ }^{70}$ In these hard cases judges had the possibility to choose from amongst different legal solutions, and they chose the one they considered to be the best. It follows from the very concept of formalism that these judgments can be problematic from a legal or constitutional point of view, but they cannot be labelled "formalist".

For the abovementioned reasons the term judicial formalism does not characterize correctly Hungarian judicial practice ${ }^{71}$ and thus it cannot serve as an explanation of judicial behavior in politically sensitive cases either.

\section{Conservative and Liberal Judges}

With regards to the ideological explanation of different forms of judicial behavior, the starting point can be an empirical study based on research carried out in 2008. The researchers examined, amongst other things, the judicial ideology in Hungary through an online survey and found that the judiciary could be divided into two groups. ${ }^{72}$ One of them, to put it simply, can be called "liberals" who think that the main justifying principle of judicial activity is the defense of the individual liberties of citizens, while judges in the other group "conservatives" hold that the primary aim of judicial work is to maintain the social order. ${ }^{73}$ Both ideologies can be reconciled with the idea of the Weberian judge as both groups of judges are well-educated, competent, and responsible legal specialists.

Arguably, it is the liberal judges who make decisions against the current governmental policies. My point is that a Weberian judge can be liberal in their adjudicative activity. ${ }^{74}$ This is so because in a broader conception of law-rights, values, and principles are organic parts of the legal system. ${ }^{75}$ Legal expertise also includes the recognition of certain values and principles as valid legal arguments which can be applicable under special circumstances. Thus, it is not against the Weberian approach to adjudication, if the legal reasoning of the judge contains not only the dimension of values, which could make a decision unpredictable, but the dimension of "fit"; that is, legal reasoning has to be coherent with the existing judicial practice. ${ }^{76}$ The latter requirement serves the enforcement of legal certainty.

\footnotetext{
${ }^{69}$ Nonetheless, these kind of decisions can be formalistic in their justification. "Justificatory formalism" means that the judge presents their decision as if it followed from the text of the applicable law, while they based their decision on other, hidden, considerations. See Marcin Matczak Mátyás Bencze \& Zdênek Kühn, EU Law and Central European Judges: Administrative Judiciaries in the Czech Republic, Hungary and Poland Ten Years after the Accession, in CENTRAL European Judges under the European Influence. The Transformative Power of the EU Revisited, 43-71 (Michal Bobek ed., 2015).

${ }^{70}$ For a detailed explanation of the impossibility of being formalist—minimalist—for a judge, see Anya Bernstein \& Glen Staszewski, Judicial populism, 5 BUfF. LEGAL STUD. RsCH. PAPER, 29-34 (2020), https://poseidon01.ssrn.com/delivery.php? $\mathrm{ID}=3110710730290711100901080040911221200350550260270310231010891121090041200921241270090030431200521180$ 450431161260871270921160180130800710410771221020890050770200190070190040940880980650250090291140710970750670 $71070030025004087092105077071012110070117 \& E X T=$ pdf\&INDEX=TRUE.

${ }^{71}$ See Péter Cserne, Formalism in Judicial Reasoning: Is Central Europe a Special Case?, in Central European Judges under the European Influence. The Transformative Power of the EU Revisited, 23-42 (Michal Bobek ed., 2015).

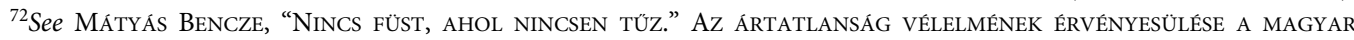
BÜNTETÖBÍRÓSÁGOK GYAKORLATÁBAN, 142-44 (2016).

${ }^{73}$ Of course, none of the judges thought that the other values which they did not rank in first place were unimportant.

${ }^{74}$ Weber himself clearly showed that well-educated, professional judges often took into consideration social values instead of formal legal rules. See Weber, supra note 33, at 882-95.

${ }^{75}$ See generally RONALD DWORKIN, LAW's EMPIRE (1986).

${ }^{76} \mathrm{See} I d$. at 225-75; MÁTYÁs BÓDIG, JOGELMÉLET ÉS GYAKORLATI FILOZÓFIA. JOGELMÉLETI MÓDSZERTANI VIZSGÁLÓDÁSOK 390 (2004).
} 
In Hungary, after the political transition, because of the constitutional turn in legal education ${ }^{77}$ in the early nineties, the indisputable authority of Constitutional Court and supranational judicial bodies-Court of Justice of the European Union (CJEU), European Court of Human Rights (ECtHR) — and the temptation to re-join Western civilization, more and more judges thought that their duty was not only to apply the letter of law, but also to defend the citizens' rights. ${ }^{78}$

Nonetheless, the Weberian model of judicial activity does not completely exclude the deferential type of adjudication. As I have shown above, there are certain features of the bureaucratic structure of court organization in Hungary which strengthen a conformist attitude, especially the present system of judicial evaluation and promotion. That is why conservative judges who originally preferred social order to individual rights can be more sensitive to pressure coming from government politicians. They may consider the government the guarantor of the preservation of the social order.

\section{Judicial Populism}

Because of the respect for judicial independence as the core value of the Hungarian judiciary the open advertisement of deference to the government's intention is far from the typical behavior even among conservative judges; the conformist adjudication relies on a new type of judicial strategy which I would call "judicial populism". This judicial strategy has emerged in the last decade in Hungary. ${ }^{79}$

The term populism in the field of legal scholarship generally refers to the behavior of the legislator. Contemporary political populism is a strategy to gain more political power by pandering to public sentiment, and professing to protect the interests of "ordinary people" against the "elite". 80 One of the obvious examples is what David Garland described as "penal populism" in the field of criminal legislation. ${ }^{81}$

It is my belief that populism plays a different role in judicial behavior. Ordinary judges very rarely aspire for governmental power. That is why in the field of judicial practice, populism, at least in the form I examine it, is not a means to gain more political power. Staszewski and Bernstein characterize judicial populism in the US context as a judicial reasoning style which shares the general criteria of authoritarian political populism: Oversimplification of complex problems, denying pluralism, antipathy toward mediating institutions, claiming exclusive representation of the unified people, Manichean thinking. ${ }^{82}$ The court decisions they cite, however, rather prove the partisan bias of some judges disguised by justificatory formalism ${ }^{83}$ than the

\footnotetext{
${ }^{77}$ See Nóra Chronowski, Az alkotmányjog oktatása az alaptörvény után - indoktrinációmentesen?!, 1 FUNDAMENTUM 33, 34 (2013); András Jakab, A magyar alkotmányjog-tudomány története és jelenlegi helyzete, in A JOG TUDOMÁNYA 178, 192 (András Jakab \& Attila Menyhárd eds., 2015).

${ }^{78}$ See Kühn, supra note 66 , at 532.

${ }^{79} \mathrm{I}$ have written about this phenomenon in more detail in another Article. See Mátyás Bencze, Explaining Judicial Populism in Hungary - a Legal Realist Approach, 1 IURIS DiCTIO REvista DE DERECHO 83-96 (2020). Some of the following paragraphs of the present Article are identical with those of that previous Article.

${ }^{80}$ See generally Margaret Canovan, Populism (1981).

${ }^{81}$ David Garland, The CUlture of CONTrol: Crime AND SOCIAL ORder IN CONTEMPORARY SOCIETY (2001).

${ }^{82}$ See Bernstein \& Staszewski, supra note 70 , at 2.

${ }^{83}$ The authors argue that some judicial methods such as using syllogism in judicial reasoning or textualism are vehicles of judicial populism. See Bernstein \& Staszewski, supra note 70, at 16-22, 37. In my view this kind of judicial method is same as the justificatory formalism which can help judges to obscure their real motivation and present the decision as a simple derivation from the text of the law. See Matczak et al., supra note 69. Therefore, justificatory formalism is quite the opposite of judicial populism, as the former builds the image of the unquestionable professional competence of the judges which is a genuine elitist feature of the judicial self-understanding. It is also hard to see why insensitivity to the consequences of a judicial decision would be a sign of judicial populism. One might rather think that it is the sign of the elitist attitude of the judge who lives in an ivory tower. Cf. Bernstein \& Staszewski, supra note 70, at 13.
} 
existence of populism among judges. ${ }^{84}$ Also, it follows from their account that even the most unpopular judgment should be labelled populist if its justification fulfils the criteria listed above. In other words, they extract the pursuit of popularity from the concept of judicial populism.

I agree with Tanasescu, who says that populist courts "defer to populist feelings and tilt the scale in favor of perceived majoritarian views, be it to become popular or to avoid popular resentment." 85 In other words, populism in a judicial context means that judges do not tend to confront the perceived opinion of the vast majority of people or powerful social groups and organizations.

One of the essential features of judicial populism is that judges deciding certain cases feel bound to the views and sentiments of the "ordinary man or woman." This serves as a solid point of orientation for a populist judge in delivering a judgment.

There might be two main reasons for a judge to follow a populist adjudicative method. When a judge truly believes that they have to take into consideration the interests and opinions of ordinary people, we can refer to this as "honest populism." This kind of judicial populism is a judicial ideology which is sensitive to the real needs of the population and follows certain long-term social aims. In this regard "Magnaud, the good judge" can be the role-model of an honestly populist judge. ${ }^{86}$ In a certain sense it is similar to the original political populism which emerged in the United States around 1890 and which, following a progressive direction, tried to reform the political and economic institutions of the country. ${ }^{87}$

Alternatively, populism may also serve as a kind of judicial strategy, where judges follow a purpose by applying this strategy, which can be clearly distinguished from the purpose of satisfying public needs and sentiments. Strategic populism, for example, may serve as a shield that can help judges, under uncertain political circumstances, to secure their institutional positions through the external support of the public sphere. ${ }^{88}$ Following from this, a strategic populist judge does not reflect on the deeper social consequences of their decision. What matters for them is the immediate reaction from the media and ordinary people to their decision. The Hungarian form of judicial populism, as I explain below, belongs to the sphere of the latter understanding of the term.

The emergence of populist adjudication has been facilitated by two tendencies, namely the politicization and the mediatization of adjudication. ${ }^{89}$ With increasing frequency over the past three decades, sensitive political cases have been brought before courts. ${ }^{90}$ Moreover, in somemostly criminal—cases, court judgments have themselves acquired political significance. ${ }^{91}$

Since the early nineties, the media has also paid increasing attention to court trials, and court trials have been more and more frequently broadcast. Some interesting cases are watched by tens

\footnotetext{
${ }^{84}$ The authors claim, for example, that "executivism" is a feature of populist legal thinking. See Bernstein \& Staszewski, supra note 70, at 26-28. It would be illuminating to compare the decisions of "executivist" judges made under conservative presidencies to those rendered under democrat presidents.

${ }^{85}$ See Elena Simina Tanasescu, Can Constitutional Courts become populist?, in ThE Role OF COURTS IN CONTEMPORARY LEGAL ORDERS 310 (Martin Belov ed., 2019). Interestingly, she also includes in the category of judicial populism cases in which a court decides in favor of a populist government even if the decision is highly unpopular amongst the populace. In my view this is not an example of judicial populism but judicial deference. See id. at 315.

${ }^{86}$ See Max Radin, The Good Judge of Château-Thierry and His American Counterpart, 4 CAL. L. REV., 300-10 (1922).

${ }^{87}$ See generally Lawrence Goodwyn, The Populist Moment (1978).

${ }^{88}$ This might be the case, for example, in Pakistan. See Anil Kalhan, Beyond Judicial Populism, THe Express TrIBUNE (Dec. 23, 2013), http://tribune.com.pk/story/649601/beyond-judicial-populism/. And recently in the EU where the CJEU adjusted its jurisprudence to the changing public mood in 'welfare migration' cases. See Michael Blauberger, Anita Heindlmaier, Dion Kramer, Dorte Sindberg Martinsen, Jessica Sampson Thierry, Angelika Schenk \& Benjamin Werner, ECJ Judges Read the Morning Papers. Explaining the Turnaround of European Citizenship Jurisprudence, 10 J. EUR. PUB. POL'Y, 1422-41 (2018)

${ }^{89}$ See Péter Hack’s contribution to the conference titled “Az igazságügyi adatkezelésről és tájékoztatásról szóló törvény koncepciója” held in Szeged, Hungary, 17 January, 2014, at http://www.birosag.hu/sites/default/files/jegyzet_0207_oszesitett_ javitott_ta_0.pdf.

${ }^{90}$ See Tímea Drinóczi \& Agnieszka Bień-Kacała, Illiberal Constitutionalism in Hungary and Poland: The Case of Judicialization of Politics, in Liberal CONSTITUTIONALISM - BETWEEN INDIVIDUAL AND COLLECTIVE INTERESTS, 67-98 (Agnieszka Bień-Kacała ed, 2017).

${ }^{91}$ I analyze below the "Rezesova" case which is a good example of this phenomenon.
} 
of millions of viewers on a daily basis in the form of a TV show. The presence of journalists and TV cameras may have an impact on the behavior of judges. It has been already detected that in some countries court decisions are sometimes influenced by popular sentiment. ${ }^{92}$

In Hungary the tendency towards penal populism in politics, ${ }^{93}$ and the mediatization and politicization of the courts have also occurred over the past fifteen years, ${ }^{94}$ creating the preconditions for strategic judicial populism. A striking example of the presence of this judicial behavior is the judicial practice of hate crime cases.

Over the past few years several surveys have revealed that Hungarian courts have adopted an explicitly majority-protective legal position in hate crimes cases ${ }^{95}$ and Hungarian justice has more frequently found members of the minority Romany community guilty of a hate crime-violence against a member of a community - than non-Romany individuals ${ }^{96}$ In the field of sentencing, a significant bias can also be detected, especially in murder cases. It seems that many judges tend to impose severe sentences on perpetrators coming from ethnic minorities. In contrast, judges are sometimes more lenient when it comes to crimes committed against ethnic minorities. ${ }^{97}$

It is important to mention two facts here. On the one hand, hate crimes committed against non-Romany people almost always receive nation-wide publicity; on the other hand, a survey conducted by the Hungarian Helsinki Committee did not find any difference in sentencing between Romany and non-Romany perpetrators in robbery cases which did not trigger a threshold stimulus for the national media. ${ }^{98}$ Taking into consideration that a pro-majority mentality is one of the characteristics of populism in Central and Eastern European (CEE) countries, ${ }^{99}$ these two facts seem to support the hypothesis that the populist approach and not racism is responsible for numerous miscarriages of justice in Hungary.

Besides criminal cases, we can find the trace of judicial populism in other branches of adjudication, as well. If we scrutinize the published civil or administrative court verdicts from the past fifteen years — with only one exception ${ }^{100}$ — we cannot find cases where any fundamental rights

\footnotetext{
${ }^{92}$ For example, in India: "Far too many in the Indian judicial system are reacting and responding to public sentiment and pressure with an eye on television cameras rather with their eyes blindfolded like Lady Justice. Judicial populism has become a disease, an affliction that runs the risk of creating institutional paralysis.” See Judicial Populism, BusINESS STANDARD (Jan. 20, 2013), http://www.business-standard.com/article/opinion/judicial-populism-110122900016_1.html.

${ }^{93}$ Katalin Gönczöl, A büntető populizmus, ÉLET És IrODALOM (Sept. 6, 2013), https://www.es.hu/cikk/2013-09-06/gonczolkatalin/a-8222bunteto-populizmus8221.html.

${ }^{94} \mathrm{Hack}$, supra note 89.

${ }^{95}$ See Eszter Jovánovics \& András László Pap, Kollektív bünösség a 21. század Magyarországán: magyarellenesség vádja cigányokkal szemben két emblematikus perben, 3 FundAMENTUM 153 (2013); Mátyás Bencze, Gyülölet-büncselekmények és 'itélkezési populizmus', 1-2 FUnDAMENTUM, 129 (2014).

${ }^{96}$ In the five officially published cases up to 2014 where the accusation was violence against a member of the Romany community courts only once found the defendant(s) guilty in that type of crime (author's own research). See also Eszter Jovánovics, A tárgyalótermek fantomja: a rasszista cigány, TASz (Feb. 20, 2013), http://ataszjelenti.blog.hu/2013/02/20/a targyalotermek_fantomja_a_rasszista_cigany. Ironically enough, the objective of the legislation which introduced hate crime into the Penal Code was to protect vulnerable minorities. Törvényjavaslat a Büntetõ Törvénykönyvrõl szóló 1978. évi IV. törvény módosításáról (Hung.), http://www.parlament.hu/iromany/fulltext/00548txt.htm.

${ }^{97}$ See Bencze, supra note 95 at 133-36; Borbála Ivány, Minősithetetlen szigorúság, Szuverén (July 27, 2012), http://www. szuveren.hu/jog/minosithetetlen-szigorusag.

${ }^{98}$ See Anna Bárdits, András Kristóf Kádár, Nóra Novoszádek, Bori Simonovits, Dóra Szegö \& Dániel Vince, Last Among Equals - The Equality Before the law OF VUlNerable Groups IN THE CRIMINAL JUSTICE SYSTEM 127 (2014).

${ }^{99}$ See Daniel Smilov, The Rule of Law and the Rise of Populism: A Case Study of Post-Accession Bulgaria, in ConstitUTIONAL Evolution In CENTRAL AND EASTERn Europe: ExpANSION AND INTEGRATION IN THE EU 253 (Kyriaki Topidi \& Alexander H. E. Morawa eds., 2010).

${ }^{100}$ In 2016 in a protest against the new Polish abortion law in the front of the Polish Embassy some participants of the demonstration performed a parody of a Catholic ritual where they changed the sacramental bread to an abortion pill. The Curia found that the performance cannot be qualified as defamation of the Catholic Church. See Szurovecz Illés, A Kúria szerint türniük kell a katolikusoknak, ha „abortusztabletta” feliratú tasakból adják az „ostyát”, 444 HU (Nov. 23, 2019), https://444.hu/ 2019/11/23/a-kuria-szerint-turniuk-kell-a-katolikusoknak-ha-abortusztabletta-feliratu-tasakbol-adjak-az-ostyat. It must be noted, that in 2021 the Constitutional Court annulled the judgment and ordered a new procedure in which the court has to
} 
would have overridden the right to religious freedom or religious sentiments in cases where one of the parties was the Catholic Church itself. It is an important feature of all these cases that the legal correctness of the judgements was highly controversial. ${ }^{101}$ According to the results of the last two censuses, it is obvious that Roman Catholic community is by far the most populous religious group in Hungary. ${ }^{102}$ A plausible explanation of the legally arguable decisions, therefore, is the pro-majoritarian populism of the courts.

The judicial practice presented above can be explained by public choice theory which sees courts as players in the arena of governmental politics, who tend to enforce their institutional interests by applying various strategies. I find it possible that Hungarian courts use a populist strategy in some cases as a means of fulfilling their institutional purposes - increasing the level of public trust toward courts by rendering popular decisions.

Nonetheless, judicial populism in its strategic form represents a danger to judicial autonomy, as a strong political party or a government can manipulate the public mood in many ways according to its own political agenda. Thus, conformist judges can justify their deferential decision by referring to their sensitivity to the people's sense of justice.

A good illustration of this manipulation is the so-called Rezesova case from $2013 .{ }^{103}$ A Slovak woman, a mother of two, killed four people in a car accident when driving recklessly on a Hungarian motorway. ${ }^{104}$ It is important to know that the perpetrator is a millionaire who has been often seen on the front pages of Slovakian tabloids. The Hungarian court of first instance sent her to prison for six years, ${ }^{105}$ at the same time, however, releasing her from detention and ordering her to be on house arrest until the final decision of the appellate court was delivered. ${ }^{106}$ The decision on house arrest provoked a huge public outcry. ${ }^{107}$ Nine days later the appellate court changed the decision on house arrest and re-ordered post-charge detention, explaining its decision with the flight risk of the defendant. ${ }^{108}$ The appellate court presented no evidence as regards a planned flight attempt, simply stating that she was rich enough to organize her own escape, even from a house arrest. ${ }^{109}$ In 2014 the appeal court increased her prison sentence to nine years. One of the reasons for the aggravation was that the accident caused huge public outcry. ${ }^{110}$

In fact, this huge public outcry was largely generated by the government through the media. One prominent member of the governing party, shortly after the judgement of the trial court, took along a cameraman and delivered a short message in front of Rezesova's residence, which he placed on his Facebook site. He expressed his disgust and, in the name of the Fidesz parliamentary faction, called on the parliamentary committee dealing with legal matters and on the minister of

examine whether the performance contributed to a public debate or aimed only at harassing Catholics. See András Király, Ujj eljárásra kötelezte a bíróságot az Alkotmánybiróság egy nőjogi tüntetés ügyében, 444 HU (Feb. 5, 2021), https://444.hu/2021/02/05/ uj-eljarasra-kotelezte-a-birosagot-az-alkotmanybirosag-egy-abortuszellenes-tuntetes-ugyeben.

${ }^{101}$ See generally Mátyás Bencze \& Richárd Drótos, A társadalmi tekintély szerepe az itélkezésben - tradicionális keresztény egyházak jogai és érdekei a magyar bíróságok elött, 3 ÁlLAM- És JoGTUDOMÁNY 3 (2015).

${ }^{102} 51,9$ percent of the population in 2001 and 37,1 percent in 2011. See http://www.nepszamlalas2001.hu/hun/kotetek/05/ tables/load1.htmlandhttps://www.ksh.hu/docs/hun/xftp/idoszaki/nepsz2011/nepsz_10_2011.pdf (last visited Sept. 8, 2021).

${ }^{103}$ Gödöllői Járásbíróság [Gödöllő District Court] 2. B. 337/2013/186-I (Hung.).

${ }^{104} \mathrm{Id}$.

${ }^{105} \mathrm{Id}$.

${ }^{106}$ Gödöllői Járásbíróság 2. B. 337/2013/186-II (Hung.).

${ }^{107}$ For the media reaction, see Political Interference with the Hungarian Judiciary, Hungarian SPECTRUM (Dec. 5, 2013), https://hungarianspectrum.org/2013/12/05/political-interference-with-the-hungarian-judiciary/.

${ }^{108}$ Budapest Környéki Törvényszék [Budapest Environs Regional Court] Bkf. 1033/2013/3 (Hung.).

${ }^{109} \mathrm{Id}$.

${ }^{110}$ See Kata Janecskó, Súlyosbitották Rezesova büntetését: kilenc év börtön, INDEX.HU (Sept. 11, 2014), https://index.hu/ belfold/2014/09/11/rezesova_masodfok_itelet/; Appellate Court Raises Rezesova Prison Sentence to 9 Years, DAILY NEws HUNGARY (Sep. 11, 2014), https://dailynewshungary.com/appellate-court-raises-rezesova-prison-sentence-to-9-years/. 
justice to investigate the outrageous decision that the defendant could spend her time between the two trials in the comfort of her home. ${ }^{111}$

One of the preconditions for the spread of populist judicial attitudes can be a certain feature of the Weberian judiciary. As Hilbink argues, ${ }^{112}$ an institutional design of the court system, in which the career of a junior judge depends heavily on the evaluation of higher-ranking judges, strengthens judicial conformity and discourages judges from thinking and deciding autonomously. A judge who is socialized to accept expectations from above cannot be sufficiently resistant to other kinds of pressure which come from outside of the court system, often from politicians or from the media. As I have shown, the opinion of higher ranked judges is decisive in the promotion of a judge, thus they have to accommodate the expectation of their superiors. Besides this, judges have noticed that court leaders have not defended them and their autonomy in a determined manner against attacks from governmental politicians and governmental media.

\section{F. Conclusion}

For historical reasons the governance of the Hungarian judiciary is highly centralized and judges are under administrative control, with the exception of their decision-making activity. The bureaucratic model of the judiciary is not necessary a negative phenomenon and fits the continental model of the judicial system. A Weberian judge is a competent, unbiased, effective, and independent civil servant and not a subordinate of any government. That is why, currently, one can find judges in Hungary who have remained loyal to judicial values such as neutrality, impartiality, and autonomy. This follows from the rational-legal legitimacy of the Hungarian judiciary which is based on the law and formalized procedures. In the eyes of these kinds of judges, politics can only be an interference in professional activity and will reduce its efficiency. ${ }^{113}$ The Weberian mentality can also be reconciled with the broad conception of law in which rights, principles, and values are also part of the law. This hypothesis is proved by a series of recent decisions made by Hungarian courts which were not in favor of the governmental parties.

Yet, the subjective elements of the bureaucratic control over judges in Hungary can incentivize some members of the judiciary to please the immediate superiors who evaluate them and decide on their career within the judiciary. This can represent a threat to autonomous decision-making. The submissive mentality, together with the "populist Zeitgeist"114 may have a detrimental effect on judicial autonomy. If the government manipulates the masses and social media, it can also shape the public mood. Judges who serve this fabricated public mood can easily become the unconscious agents of authoritarian politics.

Nonetheless, it is important to highlight the fact that dominance of subjective elements of the administrative control over the Hungarian judiciary is not an organic part of the bureaucratic model. The role of the subjective methods in the system of the evaluation of judges can be reduced and can be replaced by the application of automatic and objective control mechanisms.

\footnotetext{
${ }^{111}$ Supra note 107 .

${ }^{112}$ Hilbink, supra note 7 , at 129-31.

${ }^{113}$ Max Weber, The Theory of Social and Economic Organization 131-32 (A. M. Henderson \& Talcott Parsons trans., Talcott Parsons ed., 1947).

${ }^{114}$ Cas Mudde, The Populist Zeitgeist, 39 Gov't \& Opposition 541-63 (2004).
} 